\title{
ANALISIS PENGGUNAAN BENFORD'S LAW DALAM PERENCANAAN AUDIT DI DIREKTORAT JENDERAL BEA DAN CUKAI CABANG KOTA LHOKSEUMAWE
}

\author{
Murhaban $^{1}$, Jufrizal $^{2}$ \\ ${ }^{1,2}$ Prodi Akuntansi Fakultas Ekonomi dan Bisnis Universitas Malikussaleh Lhokseumawe \\ murhaban@unimal.ac.id
}

\begin{abstract}
This study aims to analyze the use of Benford's Law in Audit Planning at the Directorate General of Customs and Excise, Lhokseumawe City. The data used in this study are secondary data obtained directly from the Directorate General of Customs and Excise, Lhokseumawe City in 2015-2017. Data analysis methods used in this study are First Digits, Second Digits, and Three Digits. The results show that Benford's Law requirements analysis meet the requirements, and from the results of the Benford's Law data analysis, there are differences in the actual frequency data patterns with the Benford's Law frequency pattern, and also from the differences in frequency patterns that show that Benford's Law is effective and could be used to detect predictions of audit findings appropriately.
\end{abstract}

Keywords: Benford's Law, Audit Planning.

\section{PENDAHULUAN}

Sebagaimana diketahui bahwa Benford's Law dapat digunakan untuk memprediksi frekuensi kemunculan sebuah angka dalam serangkaian data numerik. Berdasarkan kemampuannya dalam menganalisis anomali data pada sebuah data set, Benford's Law banyak digunakan dalam berbagai bidang. Hal ini dijelaskan oleh Nigrini (2000). Lebih lanjut, anomali data tersebut dapat membantu dalam mendeteksi fraud. Arkan (2010) memaparkan bahwa Nigrini merupakan peneliti pertama yang secara ekstensif menggunakan Benford's Law dalam data akuntansi untuk tujuan mendeteksi fraud.

Benford's Law terbukti efektif dalam mendeteksi fraud dalam data akuntansi (Durtschiet al.,2004). Anomali yang terjadi pada suatu set data dapat mengindikasikan terjadinyafraud. Dengan demikian Benford's Law dapat menjanjikan kinerja yang lebih baikapabila dapat diterapkan pada perencanaan audit kepabeanan.

Dalam Undang-Undang Nomor 17 tahun 2006 tentang Perubahan Atas Undang-Undang Nomor 10 tahun 1995 Tentang Kepabeanan menyebutkan bahwa fungsi Direktorat Jenderal Bea dan Cukai (DJBC) adalah sebagai revenue collector, trade facilitator, industrial assistance dan community protector. Konsekuensi sebagai instansi yang memiliki fungsi memungut bea masuk dan cukai yang merupakan pendapatan negara (revenue collector), menuntut aparat Direktorat Jenderal Bea dan Cukai untuk melakukan pengawasan yang ketat. Namun di sisi lain sebagai fasilitator perdagangan (trade facilitator) aparat Direktorat Jenderal Bea dan Cukai juga dituntut untuk menerapkan pelayanan yang prima kepada masyarakat.

Salah satu bentuk fasilitas yang diberikan kepada perusahaan importir dan eksportir adalah pelaporan secara self-assessment, perusahaan menetapkan dan melaporkan sendiri nilai importasinya. Terdapat kecenderungan alami, biasanya importir ingin membayar bea masuk dan pajak dalam rangka impor dengan jumlah sekecilkecilnya. Mereka melakukan kecurangan (fraud) misal dengan cara menurunkan nilai invoice (under invoicing) atau dalam bentuk fraud lainnya, seperti penyelundupan barang.

Pengawasan yang dilakukan oleh Direktorat Jenderal Bea dan Cukai meliputi pengawasan pada saat kedatangan barang impor (on arrival) dan juga dengan pengawasan kemudian (post audit) atau yang disebut juga dengan audit kepabeanan. Audit kepabeanan ini bisa dilakukan secara periodik atau sewaktu-waktu. Dengan adanya audit kepabeanan, maka atas proses importasi pemasukan barang ke Indonesia, bisa diberikan pelayanan yang prima (cepat, sederhana dan murah). Hal ini disebabkan karena mekanisme pengawasan, sebagian dialihkan ke audit kepabeanan sehingga tidak mengganggu proses importasi. 
Berdasarkan pengamatan penulis, dalam melakukan pemilihan terhadap obyek audit (auditee) yang jumlahnya mencapai ratusan bahkan ribuan perusahaan, Direktorat Jenderal Bea dan Cukai belum mempunyai sistem yang memadai dalam perencanaan auditnya, terutama berkaitan dengan pemanfaatan sumber data yang dimiliki oleh Direktorat Jenderal Bea dan Cukai.Direktorat Jenderal Bea dan Cukai di sisi lain, memiliki data impor maupun ekspor yang terkomputerisasi, sehingga kaya dengan sumber data. Data yang dimiliki cukup memadai untuk dimanfaatkan dalam melakukan analisis perencanaan audit termasuk dalam hal pemilihan auditee. Salah satu alternatif yang bisa dipakai dalam melakukan manajemen resiko dalam perencanaan audit, terutama dalam pemilihan obyek audit, adalah dengan mengimplementasikan analisis digital terhadap pola distribusi kemunculan angka, yaitu dengan Benford's Law

Sebagai mana kita ketahui bersama bahwa fenomena-fenomena yang seringkali terjadi di Direktort Jenderal Bea dan Cukai yang ada di hampir semua wilayah pabean itu sering kita dapatkan bahwa ada penyulundupan barang atau pungutan liar yang terjadi di Direktorat Jenderal Bea dan Cukai baik penyulundupan barang impor dan barang ekspor maupun pungutan-pungutan liar yang terjadi di setiap daerah pabean atau di setiap pelabuhan-pelabuhan yang merupakan tempat lalu lintas barang ekspor maupun impor,dan juga tempat keluar masuk barang-barang untuk proses ekspor / impor. Dan juga seperti kasus penyulundupan blackbarry dan i-phone yang terjadi pada tanggal 11 februari 2013 di pelabuhan tanjung priuk yang terjerat empat pegawai direktorat jenderal bea dan cukai dengan pasal pencucian uang dan divonis dengan hukuman 5 tahun penjara. Dan pada saat presiden Jokowi pada tanggal 17 juni 2015 yang berkaitan dengan pelabuhan Tanjung Priok, dengan kasus korupsi dalam kasus lamanya proses dwelling time Pelabuhan Tanjung Priok,dan adapun fenomena yang terjadi di direktorat Jenderal Bea dan Cukai Cabang lhokseumawe adalah penyulundupan Rokok ilegal kasus ini terjadi pada tanggal 28 juli 2017 yang lalu,dan pada tanggal 30 Agustus 2017 terjadi penyulundupan bawang merah ilegal yang berhasil di berantas oleh Direktorat Jenderal Bea dan Cukai Kota Lhokseumawe. Maka dari itu pemerintah harus meningkatkan pengawasan untuk memberantas halhal tersebut untuk melindungi produksi dalam negeri dan juga sebagai penghasil devisa negara dalam pungutan bea dan cukai. Berdasarkan hal tersebut maka pemerintah mengeluarkan undangundang Nomor 17 tahun 2006 tentang Perubahan Atas Undang-Undang Nomor 10 tahun 1995 Tentang Kepabeanan,dan adapun yang melanggar semua ketentuan yang berlaku dalam undang- undang terebut maka akan ada sanksi atau hukuman yaitu pidana penjara paling lama 8 tahun penjara dan juga di kenakan sanksi administrasi berupa denda paling banyak Rp. 500.000.000.00 ( lima ratus juta rupiah ), penjelasan dari pasal 102 dalam UU No. 17 tahun 2006 tentang kepabeanan.

Berdasarkan kondisi di atas, penulis mencoba menganalisis salah satu data impor yang dimiliki oleh Direktorat Jenderal Bea dan Cukai, yaitu nilai pabean, dengan menggunakan Benford's Law. Data nilai pabean diuji persyaratannya terlebih dahulu untuk dianalisis dengan Benfords Law. Kemudian berdasarkan analisis data nilai pabean menggunakan Benford's Law, akan diperoleh nilai perbedaan proporsi antara data aktual pada nilai pabean dengan proporsi angkaangka yang diharapkan muncul menurut Benford's Law. Nilai perbedaan antara data nilai pabean dengan Benford's Law tersebut,

\section{TINJAUAN PUSTAKA \\ Pengertian Benford's law}

Benford's law (hukum benfords) ini pertama kali dikemukakan oleh Newcomb pada tahun 1881 (Benford,1938).Benford law pada dasarnya menyatakan bahwa angka-angka yang secara alamiah muncul mengikuti aturan tertentu. Benford menyatakan bahwa kemunculan bilangan tertentu pada digit tertentu pada suatu angka tertentu tidak mengikuti aturan yang seragam.

Benford's Law atau hukum Benfords adalah sebuah hukum yang dapat memperkirakan frekuensi kemunculan sebuah angka dalam serangkaian data numerik. Jika data numerik tersebut dihasilkan tanpa ada unsur kesengajaan, maka frekuensi kemunculan angka tersebut akan sesuai dengan harapan frekuensi dalam Benford's Law. Sebalik nya jika ada unsur kesengajaan oleh manusia untuk menciptakan sebuah kombinas angka dan dimasukkan dalam sebuah data set, maka hasil analisa Benford's Law akan menunjukkan bahwa ada angka tertentu yang lebih banyak atau lebih sedikit muncul dari yang diperkirakan.

Menurut Arkan (2010) memaparkan bahwa Nigrini merupakan peneliti pertama yang secara ekstensif menggunakan Benford's Law dalam data akuntansi untuk tujuan mendeteksi fraud. Benford's Law banyak digunakan diberbagai bidang, karena kemampuannya untuk mendeteksi anomaly data pada sebuah data set. Anomali data tersebut, jika ditelusuri lebih lanjut dapat mendeteksi fraud.

Akan tetapi supaya Benford law ini dapat diterapkan secara efektif, angka-angka dalam satu populasi tersebut harus memenuhi beberapa prasyarat yaitu :

1. tidak ada batas bawah angka tertentu 
2. lebih banyak nilai atau angka-angka kecil daripada yang besar (misalnya lebih banyak satuan, puluhan,ratusan dari pada ratusan ribuan atau puluhan jutaan).

3. Minimal 1000 data

4. Merupakan angka yang natural (bukan daftar angka berupa nomor telpon,KTP, NPWP, dan sejenisnya)

5. Berasal dari transaksi yang mirip atau serupa (misalnya data jumlah pembelian per-konsumen pada bulan tertentu).

6. Data jika diurutkan dari nilai terkecil hingga ke besar membentuk deret geometris

7. Data tersebut memiliki nilai rata-rata (mean) lebih besar dari nilai tengah (median).

8. Data tersebut memiliki nilai kewness positif

Ada enam tes utama untuk menentukan apakah suatu set data kuantitatif dan mengikuti pola Benford's Law atau tidak. Uraian enam tes tersebut adalah First-Digit Tes (FD), Second-Digit Tes(SD), Three-Digit Tes (TD), First-Two Digit Tes(F2D), First-Three Digit Tes (F3D), dan LastTwo Digit Tes(L2D).

\section{Perencanaan Audit}

Menurut Standar pekerjaan lapangan pertama Profesional Akuntan Publik (SPAP) mensyaratkan adanya perencanaan yang memadai yaitu: Pekerjaan harus direncanakan sebaik-baiknya dan jika digunakan asisten harus disupervisi dengan semestinya. (IAI, 2001).mensyaratkan agar audit dirancang untuk memberikan keyakinan memadai atas pendeteksian salah saji yang material dalam laporan keuangan'. Menurut SA Seksi 326 (PSA No. 07), Paragraf Audit No. 20 menyatakan bahwa Auditor pada hakikatnya harus dirumuskan dalam jangka waktudan biaya yang wajar.

Perencanan audit merupakan tahap yang sangat penting dalam proses audit. Kualitas perencanaan audit dengan sendirinya sangat menentukan kualitas tahap-tahap audit berikutnya. Sehingga perencanaan audit yang baik dapat mencegah kesalahan pada tahap-tahap audit, yang pada akhirnya memperkecil kemungkinan kegagalan audit.

\section{Penelitian Terdahulu}

Dalam melakukan penelitian ini penulis mengacu kepada beberapa beberapa penelitian terdahulu, yang berkaitan dengan penelitian ini 1. Tunjung dan andhariani (2007)

meyatakan bahwa,nilai pabean memenuhi persyaratan untuk dilakukan analisis benford law dan terjadi pola penyimpangan frekuensi angka pada data nilai pabean.Objek penelitian adalah di direktorat jenderal bea dan cukai IV Jakarta.

2. Purwoko (2004)

Hasil penelitian yang dilakukan oleh Purwoko (2004) yang meneliti tentang penggunaan profil importing dalam menggunakan regresi logistik,dia menyatakan bahwa dengan menggunakan profil importing dapat memprediksi temuan audit besar dan temuan audit kecil.

3. Wibisono (2009)

Hasil penelitiannya ) meneliti mengenai analisis kefektifan benford law dalam mendeteksi fruad dalam bidang kepabean.hasil penelitiannya bahwa nilai pabean Memenuhi persyaratan untuk dilakukan analisis benford law dan terjadi polapenyimpangan frekuensi angka pada data nilai pabean.Objek penelitian adalah di direktorat jenderal bea dan cukai IV Jakarta.

3. Muhamad Mufti Arkan (2010)

Hasil penelitiannya menunjukkan bahwa mengenai analisis penggunaan benford law dalam perencanaan audit.hasil penelitian ini menunjukkan bahwa nilai pabean memenuhi persyaratan untuk di analisis dengan benford law dan ada terdapat perbedaan antara data pabean direktorat jenderal bea dan cukai dengan benford law, dan juga ada terdapat perbedaan antara angka aktual pada nilai pabean dengan angka yang diharapkan berdasarkan benford law.objek penelitiannya di direktorat jenderal bea dan cukai medan.

\section{Kerangka Konseptual}

Kerangka konsep penelitian pada dasarnya adalah kerangka hubungan antara konsep-konsep yang ingin diamati atau di ukur melalui penelitian yang akan dilakukan (Notoatmodjo, 2002). Kerangka konseptual merupakan suatu bentuk proses keseluruhan dari proses penelitian. Dalam penelitian ini terdapat 4 variabel yang mana variabel dependen (Y) adalahTemuan Audit dalam perencanaan audit sedangkan variabel independen $\left(\mathrm{X}_{1}\right)$ adalah Benfords Law Pengujian First Digit (FD), $\left(\mathrm{X}_{2}\right)$ adalah Benfords Law Pengujian second Digit (SD), $\left(\mathrm{X}_{3}\right)$ adalah Benfords Law Pengujian Three Digit (TD),

\section{Gambar1 Kerangka Konseptual}

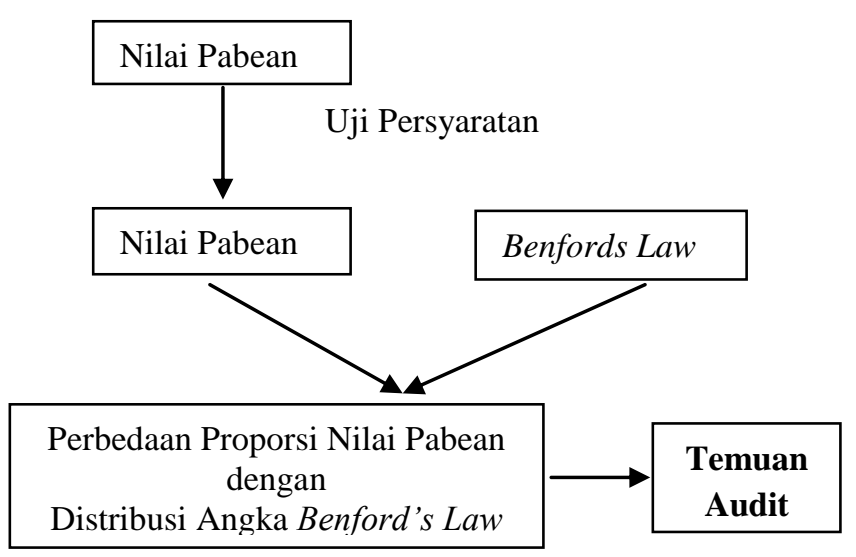


Perbedaan Proporsi

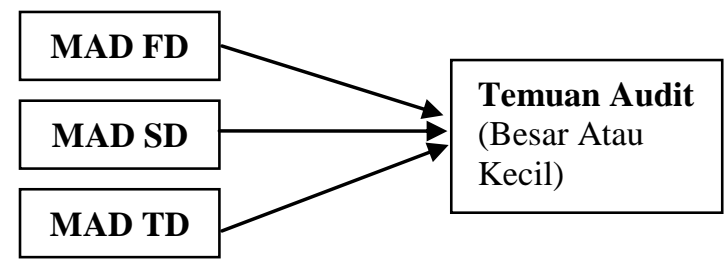

\section{METODE PENELITIAN \\ Lokasi Penelitian}

Adapun penelitian ini dilakukan di kantor Pusat Direktorat Jenderal Bea dan Cukai Cabang Kota Lhokseumawe, Jalan Iskandar Muda No. 17 Kampung Jawa Lama, Kecamatan Banda Sakti, Kota Lhokseumawe. Datanya merupakan data base Direktorat Jenderal Bea dan Cukai Cabang Kota Lhokseumawe yaitu data nilai pabean.

\section{Populasi dan Sampel Populasi dan Sampel Penelitian}

Populasi adalah seluruh perusahaan yang merupakan perusahaan importir umum/produsen yang menjadi data kepabeanan, yaitu sebanyak 17 perusahaan yang terdapat dalam data transaksi kepabeanan di Direktorat Jenderal Bea dan Cukai Cabang Kota Lhokseumawe. Penelitian ini menggunakan teknik sampel dengan metode non probability sampling. Tujuan penggunaan metode non probability sampling adalah untuk mendapatkan sampel yang representative sesuai dengan kriteria yang ditentukan. Sampel dipilih adalah semua data perusahaan yang merupakan data kepabeanan yang ada di direktorat jenderal bea dan cukai cabang kota lhokseumawe, menurut Sugiyono (2011:118-127) teknik sampel dengan metode non probability sampling adalah teknik pengambilan sampel tidak memberi peluang atau kesempatan sama sekali bagi setiap unsur atau anggota populasi untuk dipilih menjadi sampel.dan teknik pengambilan sampel dalam penelitian ini menggunakan teknik sampling jenuh yaitu teknik menentukan sampel bila semua anggota populasi di gunakan sebagai sampel. Hal ini sering dilakukan jika jumlah populasinya relative kecil yakni kurang dari 30 populasi. Dengan demikian dalam penelitian ini memakai teknik penelitian tersebut karena semua populasi di jadikan sebagai sampel,karena populasi yang terdapat di data pabean direktorat jenderal bea dan cukai cabang kota lhokseumawe itu sebanyak 17 perusahaan,

\section{Definisi operasional dan pengukuran variabel}

Pada variabel operasional ini dibedakan menjadi dua katagori yaitu variabel independen dan variabel dependen.jadi variabel dalam penelitian ini, variabel terikat (dependent variable) adalah temuan audit (Y), sedangkan variabel bebas (independent variable) adalah besarnya perbedaan/penyimpangan proporsi pola frekuensi data aktual nilai pabean dengan proporsi pola frekuensi yang diharapkan menurut Benford's Law. Perbedaan tersebut meliputi perbedaan pada digit pertama (first digit/FD), digit kedua (second digit/SD) dan digit Ketiga (Three digit/TD). Besaran perbedaan tersebut diukur dengan nilai Mean Absolute Deviation (MAD).

Adapun numorik angka-angka ketentuan dari Benfords Law ini yaitu dimulai dari angka 0,1,2,3 sampai dengan angka 9 yang di analisis. Berikut tabel frekuensi yang diharapkan Benfords Law,

Tabel 1

Frekuensi yang diharapkan Benfords Law

\begin{tabular}{|c|c|c|c|c|}
\hline \multirow{2}{*}{ Digit } & \multicolumn{4}{|c|}{ Posisi } \\
\cline { 2 - 5 } & 1 & 2 & 3 & 4 \\
\hline 0 & & 0,11968 & 0,10178 & 0,10018 \\
\hline 1 & 0,30103 & 0,11389 & 0,10138 & 0,10014 \\
\hline 2 & 0,17609 & 0,10882 & 0,10097 & 0,10010 \\
\hline 3 & 0,12494 & 0,10433 & 0,10057 & 0,10006 \\
\hline 4 & 0,09691 & 0,10031 & 0,10018 & 0,10002 \\
\hline 5 & 0,07918 & 0,09668 & 0,09979 & 0,09998 \\
\hline 6 & 0,06695 & 0,09337 & 0,09940 & 0,09994 \\
\hline 7 & 0,05799 & 0,09035 & 0,09902 & 0,09990 \\
\hline 8 & 0,05115 & 0,08757 & 0,09864 & 0,09986 \\
\hline 9 & 0,04576 & 0,08500 & 0,09827 & 0,09982 \\
\hline
\end{tabular}

Sumber : ( Nigrini 1996 )

Dimana angka-angka ketentuan tersebut yang ada di ketentuan Benfords Law yaitu angka numorik dari angka 0,1,2,3, dan seterusnya sampai angka 9, yang merupakan angka 0 itu di maksud dengan frekuensi muncul angka nol dalam sebuah data set yang di analisis, begitu juga dengan angka 1 yaitu dilambangkan dengan frekuensi munculnya angka satu dalam sebuah data set yang di analisis dengan benfords Law, begitu juga seterusnya sampai angka 9 yang merupakan frekuensi muncul angka Sembilan dalam sebuah data set yang di analisis dengan hokum benfords.

Jadi yang menjadi variabel bebas dalam penelitian ini adalah nilai perbedaan antara proporsi angka aktual pada digit pertama nilai pabean dengan angka yang diharapkan benfords law (MAD FD) $\left(\mathrm{X}_{1}\right)$, nilai perbedaan antara proporsi angka aktual pada digit kedua nilai pabean dengan angka yang diharapkan benfords law (MAD SD) $\left(\mathrm{X}_{2}\right)$, nilai perbedaan antara proporsi angka aktual pada 
digit ketiga nilai pabean dengan angka yang diharapkan benfords law(MAD TD) $\left(\mathrm{X}_{3}\right)$,sedangkan yang menjadi variabel terikat (dependent) adalah temuan audit (Y) yaitu temuan audit kecil dan temuan audit besar, dimana temuan audit kecil itu yang dimaksud adalah transaksi pabean yang terjadi di bawah seratus juta rupiah yang dilambangkan dengan angka 0 pada data yang di analisis untuk memprediksi fraud dalam sebuah data set, dan temuan audit besar itu juga yang dimaksud adalah transaksi pabean yang terjadi di atas seratus juta rupiah di lambangkan dengan angka 1 pada data yang di analisis untuk memprediksi fraud dalam sebuah data set.

Tabel 2

Tabel Definisi Operasional Variabel

\begin{tabular}{|c|c|c|c|}
\hline $\begin{array}{l}\text { Varia } \\
\text { bel }\end{array}$ & $\begin{array}{l}\text { Ketera } \\
\text { ngan }\end{array}$ & Jenis & Penjelasan \\
\hline $\mathrm{X}_{1}$ & Mad Fd & $\begin{array}{l}\text { Indep } \\
\text { enden }\end{array}$ & $\begin{array}{l}\text { Nilai perbedaan } \\
\text { antara proporsi } \\
\text { angka aktual pada } \\
\text { digit pertama nilai } \\
\text { pabean dengan } \\
\text { angka yang } \\
\text { diharapkan menurut } \\
\text { Benford's Law }\end{array}$ \\
\hline $\mathrm{X}_{2}$ & Mad Sd & $\begin{array}{l}\text { Indep } \\
\text { enden }\end{array}$ & $\begin{array}{l}\text { Nilai perbedaan } \\
\text { antara proporsi } \\
\text { angka aktual pada } \\
\text { digit kedua nilai } \\
\text { pabean dengan } \\
\text { angka yang } \\
\text { diharapkan menurut } \\
\text { Benford's Law }\end{array}$ \\
\hline $\mathrm{X}_{3}$ & $\begin{array}{l}\text { Mad } \\
\text { Td }\end{array}$ & $\begin{array}{l}\text { Indep } \\
\text { enden }\end{array}$ & $\begin{array}{l}\text { Nilai perbedaan } \\
\text { antara proporsi } \\
\text { angka aktual pada } \\
\text { dua digit pertama } \\
\text { nilai pabean dengan } \\
\text { angka yang } \\
\text { diharapkan menurut } \\
\text { Benford's Law }\end{array}$ \\
\hline $\mathrm{Y}$ & $\begin{array}{l}\text { Temua } \\
\text { n hasil } \\
\text { audit }\end{array}$ & $\begin{array}{l}\text { Depe } \\
\text { nden }\end{array}$ & $\begin{array}{l}\text { Temuan hasil audit } \\
\text { dalam bentuk } \\
\text { temuan kecil } \\
\text { (kurang dari Rp } \\
100.000 .000,00, \\
\text { dilambangkan } \\
\text { dengan angka } 0 \text { ) } \\
\text { dan temuan besar } \\
\text { (Rp 100.000.000,00 } \\
\text { ke atas, }\end{array}$ \\
\hline
\end{tabular}

\section{Data dan Sumber Data}

Jenis data yang digunakan dalam penelitian ini adalah data sekunder Menurut Sugiyono,
(2014:131) data sekunder yaitu sumber data penelitian yang diperoleh peneliti secara tidak langsung melalui media perantara (diperoleh dan dicatat oleh pihak lain). jadi data sekunder merupakan data yang yang diperoleh secara tidak langsung dari objeknya, tetapi melalui sumber lain, baik secara lisan maupun tertulis. Didalam penelitian ini penulis menggunakan sumber tertulis yang terbagi atas sumber ilmiah, sumber arsip, dan dokumen resmi dari Direktorat Jenderal Bea dan Cukai Cabang Kota Lhokseumawe.

\section{Teknik Pengumpulan Data}

Untuk mengetahui penggunaan benfords law dalam perencanaan audit ini efektif atau tidak dalam melakukan pendeteksian kecurangan dalam suatu set data, dengan berbagai tes yang dilakukan maka dalam penelitian ini akan digunakan metode penelitian kuantitatif deskriptif,

\section{Metode Analisis Data}

Menurut Sugiyono, (2013:244). Analisis data adalah proses mencari dan menyusun secara sistematis data yang diperoleh dari hasil wawancara, catatan lapangan, dan bahan-bahan lain, sehingga dapat mudah dipahami, dan temuannya dapat diinformasikan kepada orang lain. Metode analisis data yang digunakan dalam penelitian ini adalah metode analisis analisis persyaratan benford's law, analisis perbedaan pola frekuensi data,analisis statistik deskriptif.

\section{HASIL PENELITIAN DAN PEMBAHASAN}

\section{Pengujian Persyaratan Benford Law}

Adapun Benford law ini dapat diterapkan secara efektif, angka-angka dalam satu populasi tersebut harus memenuhi beberapa prasyarat yaitu :

1. tidak ada batas bawah angka tertentu,Adapun data yang kami kutip di Direktorat Jenderal Bea dan Cukai Cabang Kota Lhokseumawe sudah terpenuhi syarat yaitu tidak ada pembatas bawah angka dalam data transaksi yang terjadi di Direktorat Jenderal Bea dan Cukai Cabang Kota Lhokseumawe

2. lebih banyak nilai atau angka-angka kecil dari pada yang besar (misalnya lebih banyak satuan, puluhan,ratusan dari pada ratusan ribuan atau puluhan jutaan) Dalam persyaratan ini pun sudah tepenuhi syarat nya bahwa data yang ada di Direktorat Jenderal Bea dan Cukai cabang Kota Lhokseumawe itu merupakan data nilai pabean yang nilai transaksinya hanya ratusan juta rupiah tetapi angka tersebut masih bisa di uji analisis datanya,jadi data tersebut memenuhi syarat untuk di analisis. 
3. Minimal 1000 data,Adapun data yang ada di Direktorat Jenderal Bea dan Cukai cabang Kota Lhokseumawe itu merupakan data nilai pabean yang nilai transaksinya sudah ratusan juta rupiah Jadi datanya sudah memenuhi syarat dan bisa di analisis selanjutnya.

4. Merupakan angka yang natural (bukan daftar angka berupa nomor telpon,KTP, NPWP, dan sejenisnya),Dalam persyaratan ini pun sudah tepenuhi syarat nya bahwa data yang ada di Direktorat Jenderal Bea dan Cukai cabang Kota Lhokseumawe itu merupakan data nilai transaksi pabean yang merupakan nilai natural yaitu nilai / angka-angka yang terjadi dengan sendirinya.

5. Berasal dari transaksi yang mirip atau serupa (misalnya data jumlah pembelian per-konsumen pada bulan tertentu).Adapun data yang ada di Direktorat Jenderal Bea dan Cukai cabang Kota Lhokseumawe itu merupakan data nilai transaksi pabean yang sudah di akumulasi pertahun periode.

6. Data jika di urutkan dari nilai terkecil hingga ke besar membentuk deret geometris,Data juga bisa di urutkan dari yang terkecil sampai yang besar sehingga berbentuk deret geometrik, jadi data tersebut bisa di analisis selanjutnya karena sudah memenuhi syaratnya.

7. Data tersebut memiliki nilai rata-rata (mean) lebih besar dari nilai tengah (median).

8. Data tersebut juga memiliki nilai kewness positif.

\section{Pengujian Pola Frekuensi Benford Law}

Adapun yang menjadi variabel bebas dalam penelitian ini adalah nilai perbedaan antara proporsi angka aktual pada digit pertama nilai pabean dengan angka yang diharapkan benfords law (MAD FD) (X1), nilai perbedaan antara proporsi angka aktual pada digit kedua nilai pabean dengan angka yang diharapkan benfords law (MAD SD) (X2), nilai perbedaan antara proporsi angka aktual pada digit ketiga nilai pabean dengan angka yang diharapkan benfords law (MAD TD) $\left(\mathrm{X}_{3}\right)$,sedangkan yang menjadi variabel terikat (dependent) adalah temuan audit (Y).

\section{Hasil Penelitian Variabel $X_{1}$, digit pertama (first digit/MAD FD)}

Adapun dalam pengujian ini peniliti akan menganalisis tentang analisis Benfords Law yaitu analisis first digit, Dengan menggunakan data Transaksi Pabean Direktorat Jenderal Bea dan Cukai Cabang Kota lhokseumawe tahun 2015 Sampai dengan Tahun 2017
Adapun grafiknya dapat dilihat

Gambar 2 Grafik Hasil Uji Firt Digit Data Tahun 2015

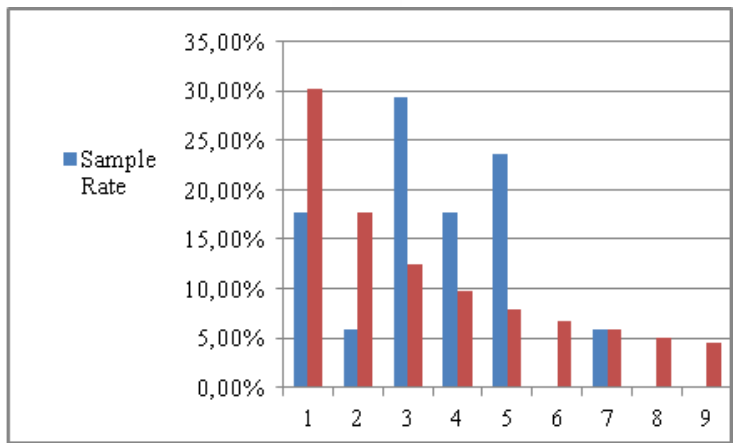

Jadi peniliti menyimpulkan bahwa pada pengujian ini bahwa angka 7 yang sesuai dengan hukum benford, angka yang lain yaitu dari angka 1,2,3,4,dan 5, itu menunjukkan bahwa grafik proporsi frekuensinya tidak searah atau tidak sesuai dengan harapan Benford Law,jadi bisa kita ambil kesimpulan bahwa data angka numorik tersebut perlu di teliti lebih dalam karena menurut deteksi benford law dari data tersebut memiliki unsur kecurangan.

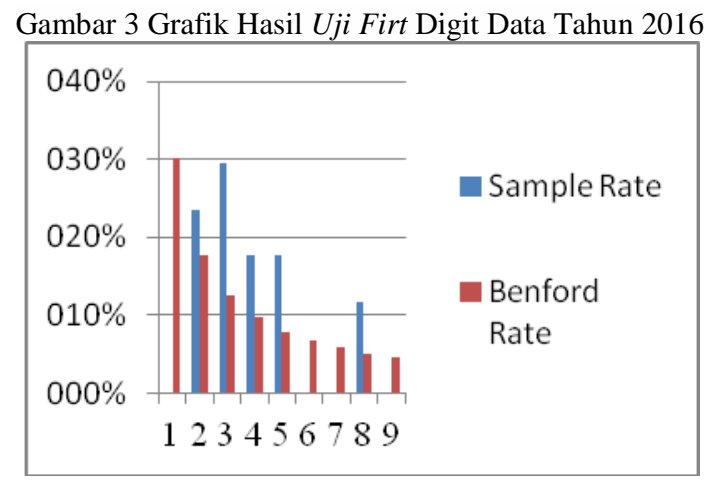

Jadi dapat kita tarikkesimpulan bahwa pada pengujian ini bahwa tidak ada angka satupun yang muncul yang sesuai dengan hukum benford, maka menunjukkan bahwa grafik proporsi frekuensinya tidak searah atau tidak sesuai dengan harapan Benford Law,jadi bisa kita ambil kesimpulan bahwa data angka numorik tersebut perlu di teliti lebih dalam karena menurut deteksi benford law dari data tersebut memiliki unsur kecurangan

Gambar 4. Grafik Hasil Uji Firt Digit Data Tahun 2017 


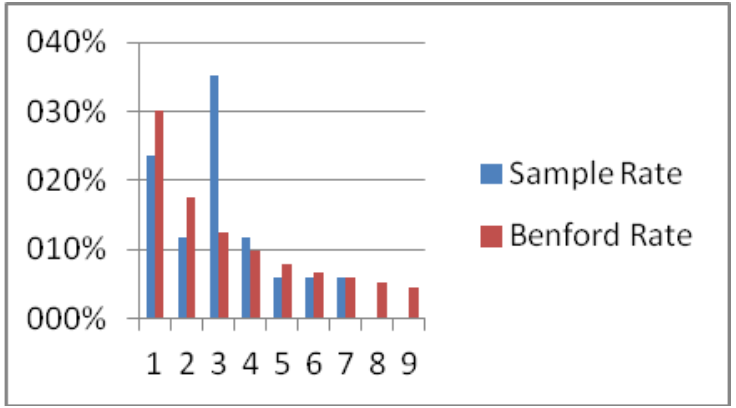

Jadi peniliti menyimpulkan bahwa pada pengujian ini bahwa angka 7 dan 4 yang sesuai dengan hukum benford, angka yang lain yaitu dari angka 1,2,3,5, dan 6 itu menunjukkan bahwa grafik proporsi frekuensinya tidak searah atau tidak sesuai dengan harapan Benford Law,jadi bisa kita ambil kesimpulan bahwa data angka numorik tersebut perlu di teliti lebih dalam karena menurut deteksi benford law dari data tersebut memiliki unsur kecurangan,dan dari grafik tersebut angka 3 yang besar akan frekuensi akan muncul indikasi kecurangan.

\section{Hasil Penelitian Variabel $\mathbf{X}_{2}$, Digit kedua (second digit/MAD SD)}

Adapun dalam pengujian ini peniliti akan menganalisis tentang analisis Benfords Law yaitu analisis Second digit, yaitu pengujian digit kedua Dengan menggunakan data Transaksi Pabean Direktorat Jenderal Bea dan Cukai Cabang Kota lhokseumawe tahun 2015 Sampai dengan Tahun 2017 ,

Adapun grafiknya menunjukkan bahwa :

Gambar 5 Grafik Hasil Uji Second Digit Data Tahun 2015

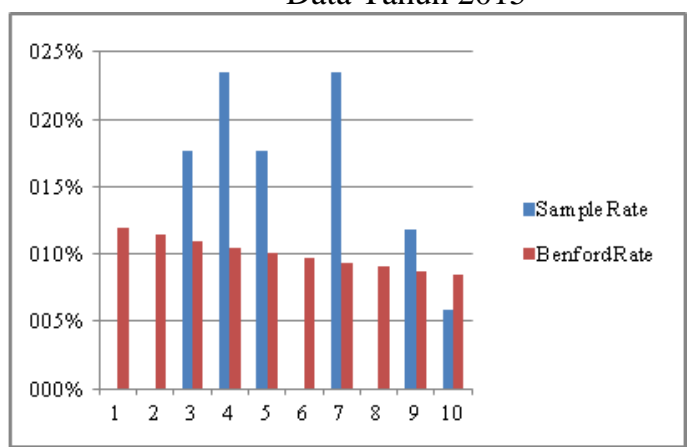

Jadi peniliti dapat menyimpulkan bahwa pada pengujian ini semua angka yang di analisis menunjukkan tidak sesuai dengan harapan hukum benford, maka dari itu grafik menunjukkan bahwa proporsi frekuensinya tidak searah atau tidak sesuai dengan harapan Benford Law,jadi bisa kita ambil kesimpulan bahwa data angka numorik tersebut perlu di teliti lebih dalam karena menurut deteksi benford law dari data tersebut memiliki unsur kecurangan.
Gambar 6 Grafik Hasil Uji Second Digit Data Tahun 2016

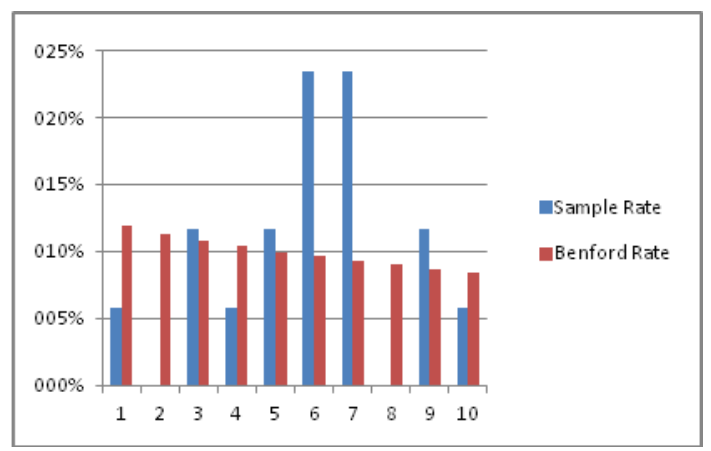

Bahwa pada pengujian ini penulis dapat menyimpulkan bahwa angka 3 dan 5 yang mendekati sesuai dengan hukum benford, angka yang lain yaitu dari angka 1,4,6,7,9 dan 10 itu menunjukkan bahwa grafik proporsi frekuensinya tidak searah atau tidak sesuai dengan harapan Benford Law,jadi bisa kita ambil kesimpulan bahwa data angka numorik tersebut perlu di teliti lebih dalam karena menurut deteksi benford law dari data tersebut memiliki unsur kecurangan,dan di angka 6 dan 7 yang menunjukkan tinggi frekuensi kecurangan dari data tersebut.

Gambar 7 Grafik Hasil Uji Second Digit Data Tahun 2017

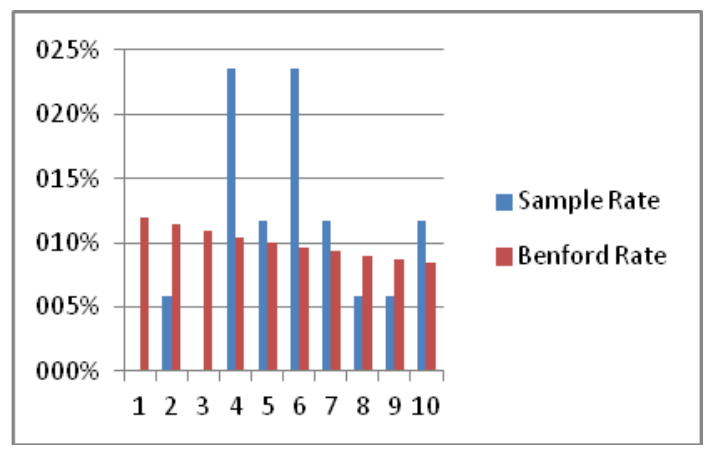

Bahwa pada pengujian ini penulis dapat menyimpulkan bahwa tidak ada angka satupun yang sesuai dengan hukum benford, menunjukkan bahwa grafik proporsi frekuensinya tidak searah atau tidak sesuai dengan harapan Benford Law,jadi bisa kita ambil kesimpulan bahwa semua data angka numorik tersebut perlu di teliti lebih dalam karena menurut deteksi benford law dari data tersebut memiliki unsur kecurangan,

\section{Hasil Penelitian Variabel $\mathbf{X}_{3}$, digit Ketiga (Three digit / MAD TD).}

Adapun dalam pengujian ini peniliti akan menganalisis tentang analisis Benfords Law yaitu analisis Three digit, Dengan menggunakan data Transaksi Pabean Direktorat Jenderal Bea dan 
Cukai Cabang Kota lhokseumawe tahun 2015 Sampai dengan Tahun 2017,

Adapun grafiknya :

Gambar 8 Grafik Hasil Uji Three Digit Data Tahun 2015

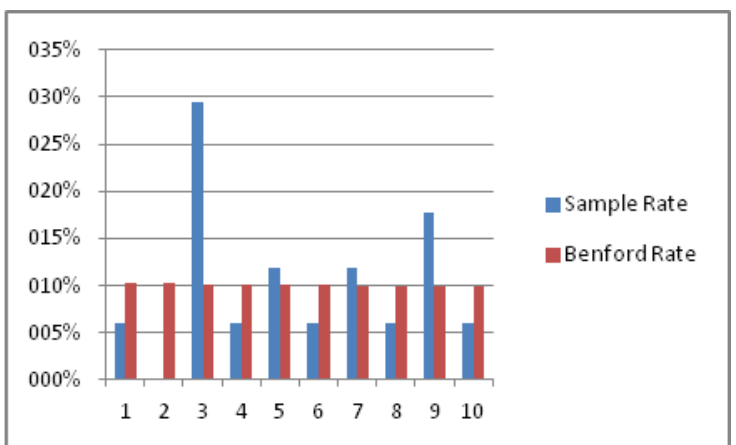

Bahwa pada pengujian ini penulis dapat menyimpulkan bahwa angka 5 dan 7 yang mendekati sesuai dengan hukum benford, angka yang lain yaitu dari angka 1,3,4,6,8,9dan 10 itu menunjukkan bahwa grafik proporsi frekuensinya tidak searah atau tidak sesuai dengan harapan Benford Law,jadi bisa kita ambil kesimpulan bahwa data angka numorik tersebut perlu di teliti lebih dalam karena menurut deteksi benford law dari data tersebut memiliki unsur kecurangan,dan di angka 3 yang menunjukkan tinggi frekuensi kecurangan dari data tersebut.

\section{Gambar 9 Grafik Hasil Uji Three Digit} Data Tahun 2016

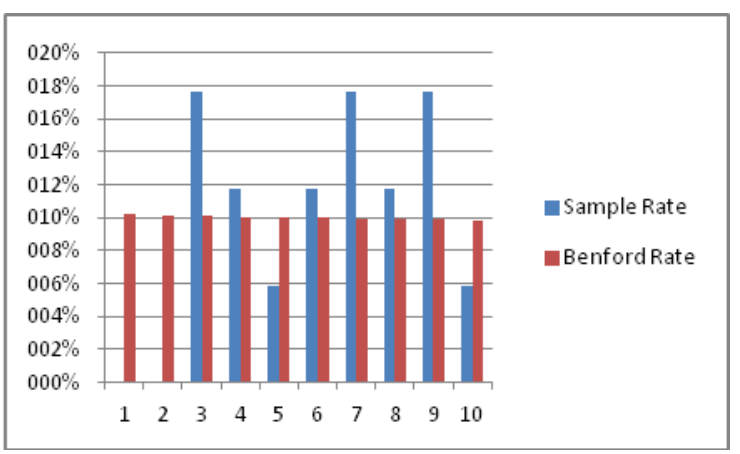

Bahwa pada pengujian ini penulis dapat menyimpulkan bahwa tidak ada angka yangsesuai dengan harapan hukum benford,grafik menunjukkan bahwa proporsi frekuensinya tidak searah atau tidak sesuai dengan harapan Benford Law,jadi bisa kita ambil kesimpulan bahwa semua data angka numorik tersebut perlu di teliti lebih dalam karena menurut deteksi benford law dari data tersebut memiliki unsur kecurangan.
Gambar 10 Grafik Hasil Uji Three Digit Data Tahun 2017

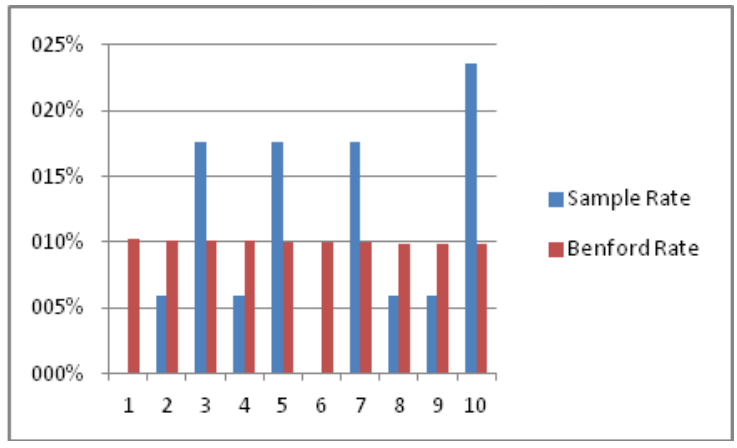

Bahwa pada pengujian ini penulis dapat menyimpulkan bahwa tidak ada angka yangsesuai dengan harapan hukum benford,grafik menunjukkan bahwa proporsi frekuensinya tidak searah atau tidak sesuai dengan harapan Benford Law,jadi bisa kita ambil kesimpulan bahwa semua data angka numorik tersebut perlu di teliti lebih dalam karena menurut deteksi benford law dari data tersebut memiliki unsur kecurangan.

\section{Hasil Penelitian Variabel Y,Temuan hasil audit.}

Adapun dalam pengujian ini peniliti akan menganalisis tentang analisis Benfords Law dalam pendeteksi temuan Audit, data yang dideteksi yaitu Data Transaksi Pabean Direktorat Jenderal Bea dan Cukai Cabang Kota lhokseumawe tahun 2015 Sampai dengan Tahun 2017, adapun datanya dimuat dalam lampiran XI.

Jadi, dari data di tabel diatas dapat kita ambil kesimpulan bahwa hasil pengujian variabel y terhadap temuan audit yaitu temuan kecil dan temuan besar, dari tabel di atas menunjukkan bahwa hanya tiga (3) perusahaan yang merupakan perusahaan yang transaksi nya hanya terjadi di bawah Rp 100.000.000.00 maka dapat kita ambil kesimpulan bahwa hanya tiga perusahaan yang terdapat dalam transaksi pabean di direktorat jenderal bea dan cukai kota lhokseumawe yang bisa kita deteksi terhadap temuan audit kecil.

Dan dari tabel di atas juga menunjukkan bahwa hanya empat belas (14) perusahaan yang merupakan perusahaan yang transaksi nya terjadi di atas Rp 100.000.000.00 maka dapat kita ambil kesimpulan bahwa terdapat empat belas (14) perusahaan yang transaksinya di atas $\mathrm{Rp}$ 100.000.000.00 yang terdapat dalam data transaksi pabean di direktorat jenderal bea dan cukai cabang kota lhokseumawe yang bisa dideteksi terhadap temuan audit besar.

\section{Statistik Deskriptif}


Adapun dari tabel dalam Lampiran XII, itu menunjukkan Nilai pabean terendah pada tahun 2015 adalah sebesar Rp 78.294.000,00 yang dimiliki oleh perusahaan MON BLANG PERKASA .Sedangkan nilai pabean tertinggi tahun 2015 adalah sebesar RP 593.357.000,00 yang dimiliki oleh perusahaan ENERGI PULAU SUJA. Adapun nilai rata-rata (mean) pabean pada tahun 2015 adalah Rp 357.000.000,00.

Pada tahun 2016, nilai pabean terendah adalah sebesar Rp 85.614.000,00 yang dimiliki oleh PT DIMA INDONESIA. Sedangkan nilai pabean adalah sebesar RP 859.254.000,00 yang dimiliki oleh perusahaan ENERGI PULAU SUJA. Adapun nilai rata-rata (mean) pabean pada tahun 2016 adalah Rp 398.000.000,00.

Untuk tahun 2017, nilai pabean terendah adalah sebesar Rp 132.489.000,00 yang dimiliki oleh PT SARANA ACEH UTAMA. Sedangkan nilai pabean adalah sebesar RP 786.705.000,00 yang dimiliki oleh perusahaan PERUM BULOG. Adapun nilai rata-rata (mean) pabean pada tahun 2017 adalah Rp 362.000.000,00.

Dengan demikian, dapat disimpulkan dari nilai rata-rata pabean periode 2015 -2016, nilai rata-rata pabean paling sedikit terjadi pada tahun 2015, yaitu sebesar Rp 357.000.000,00.

\section{Pembahasan}

Analisis Persyaratan Benfords Law Dalam
Data Nilai Transaksi Pabean Di Direktorat
Jenderal Bea dan Cukai Cabang Kota
Lhokseumawe.

Adapun dari data yang di peroleh oleh peneliti dari pada pihak Direktorat Jenderal Bea dan Cukai Cabang kota Lhokseumawe,itu sebagaimana data dapat dilihat di lampiran 1, bahwasanya data transaksi pabean yang ada di Direktorat Jenderal bea dan Cukai Cabang Kota Lhokseumawe itu sudah memenuhi persyaratan yang di syaratkan oleh hukum benfords dan sudah sesuai dengan ketentuan hukum benfords, maka dari itu data transaksi pabean yang ada di Direktorat Jenderal bea dan Cukai Cabang Kota Lhokseumawe tersebut itu bisa di analisis lebih lanjut dengan menggunakan Benfords Law untuk mendeteksi temuan audit.

Dan kemudian uji selanjudnya bisa dilakukan dengan pengujian selanjudnya yaitu pengujian First digit yaitu pengujian digit pertama dalam sebuah data, pengujian second digit yaitu pengujian digit kedua dalam sebuah data, dan pengujian three digit yaitu pengujian digit ketiga dalam sebuah data, supaya dapat dilihat bahwa dari pengujian tersebut bisa memprediksi temuan audit, dan pengujian ini di lakukan di dalam data transaksi pabean yang ada di direktorat jenderal bea dan cukai cabang kota lhokseumawe.
Penggunaan Benfords Law untuk melihat perbedaan antara nilai data transaksi pabean yang ada di Direktorat Jenderal Bea dan Cukai Cabang Kota Lhokseumawe dengan harapan Hukum Benfords.

Adapun peneliti sudah menguji atau menganalisis data transaksi pabean yang ada di Direktorat Jenderal bea dan Cukai Cabang Kota Lhokseumawe itu dengan menggunakan benfords Law yaitu test First Digit,Second Digit dan Three Digit, dan dari ketiga test tersebut menunjukkan bahwa pada pengujian First Digit pada data tahun 2015 itu menunjukkan bahwa hanya satu angka yang sesuai atau searah dengan harapan hukum benfords,yaitu angka 7 dan angka lainnya itu terdapat perbedaan atau terdapat penyimpangan sehingga angka lainnya itu tidak sesuai atau tidak searah dengan yang diharapkan Benfords Law. Begitu juga pada pengujian First Digit pada data tahun 2016 itu menunjukkan bahwa tidak satupun angka yang sesuai atau searah dengan harapan hukum benfords, sehingga data tersebut berbeda jauh dengan harapan yang di harapkan Benfords law, sehingga data tersebut perlu di teliti lebih dalam lagi karna bisa mengindikasikan adanya unsur kecurangan. Dan kemudian pengujian First Digit pada data tahun 2017 itu menunjukkan bahwa hanya ada angka 7 dan 4 yang sesuai atau searah dengan harapan hukum benfords, dan angka lainnya itu menunjukkan adanya perbedaan atau adanya penyimpangan sehingga angka lainnya itu tidak sesuai atau tidak searah dengan yang diharapkan Benfords Law.

Kemudian dalam pengujian Second Digit pada data tahun 2015 itu menunjukkan bahwa tidak ada satu angkapun yang sesuai atau searah dengan harapan hukum benfords,sehingga perlu di teliti lebih dalam karena ada indikasi kecurangan. Dan pengujian Second Digit pada data tahun 2016 itu menunjukkan bahwa angka 3 dan 5 yang sesuai atau searah dengan harapan hukum benfords, dan angka lainnya itu menunjukkan adanya perbedaan atau adanya penyimpangan sehingga angka lainnya itu tidak sesuai atau tidak searah dengan yang diharapkan Benfords Law, sehingga perlu di teliti lebih dalam karena ada indikasi kecurangan. Dan selanjutnya dalam pengujian Second Digit pada data tahun 2017 itu menunjukkan bahwa tidak ada satu angkapun yang sesuai atau searah dengan harapan hukum benfords,sehingga perlu di teliti lebih dalam karena ada indikasi kecurangan.

Adapun dalam dalam pengujian Three Digit pada data tahun 2015 itu menunjukkan bahwa angka 5 dan 7 yang sesuai atau searah dengan harapan hukum benfords, dan angka lainnya itu menunjukkan adanya perbedaan atau adanya penyimpangan sehingga angka lainnya itu tidak sesuai atau tidak searah dengan yang diharapkan 
Benfords Law, sehingga perlu di teliti lebih dalam karena ada indikasi kecurangan. dan dalam pengujian Three Digit pada data tahun 2016 itu menunjukkan bahwa tidak ada satu angka pun yang sesuai atau searah dengan harapan hukum benfords,sehingga perlu di teliti lebih dalam karena ada unsur kecurangan. Kemudian dalam pengujian Three Digit pada data tahun 2017 itu juga menunjukkan bahwa tidak ada satupun angka yang sesuai atau searah dengan harapan hukum benfords,sehingga bisa diprediksi ada unsur kecurangan. Jadi dapat peneliti simpulkan bahwa data dari hasil test First Digit, Second Digit dan Three Digit itu menunjukkan bahwa data transaksi pabean yang ada di Direktorat Jenderal Bea dan Cukai Cabang Kota Lhokseumawe tahun 20152017 itu menunjukkan bahwa terdapat perbedaan pola frekuensi dengan pola frekuensi yang di harapkan Benfords Law.

\section{Analisis Benfords Law untuk melihat perbedaan Proporsi antara nilai data transaksi pabean yang ada di Direktorat Jenderal Bea dan Cukai Cabang Kota Lhokseumawe Dengan Menggunakan Benfords LawUntuk Memprediksi Temuan Audit.}

Berdasar kan hasil uji analisis penggunaan Benfords Law dalam data transaksipabean direktorat jenderal bea dan cukai cabang kota lhokseumawe,itu menunjukkan bahwa terdapat perbedaan antara nilai aktual yang ada di data direktorat jenderal bea dan cukai cabang kota lhokseumawe itu dengan data aktual yang diharapkan hukum benfords ini,maka dari itu penggunaan benfords law dalam memprediksi temuan audit itu efektif dipakai karena berdasarkan penelitian terdahulu bahwa sanya hasil analisis perbedaan proporsi antara nilai aktual data transaksi pabean dengan nilai hasil frekuensi Benfords Law ini sudah efektif menunjukkan bahwa Benfords Law ini bisa untuk mendeteksi temuan audit dalam sebuah data set, jadi dapat peneliti simpulkan bahwa penggunaan Benfords Law ini efektif untuk memprediksi temuan audit dan bisa dipastikan untuk mendeteksi unsur kecurangan dalam suatu data yang mau di audit,

Namun dapat kita lihat bersama bahwa dari hasil pengujian ini dapat kita lihat bahwa terdapat perbedaan nilai frekuensi aktual dalam data ini dengan frekuensi harapan Benfords law maka dari itu dengan timbulnya frekuensi berbeda dengan frekuensi benfords law ini maka itu diakibatkan karena adanya kecenderungan atau kecurangan dalam penyajian data set yang disajikan oleh pihak direktorat jenderal bea dan cukai cabang kota lhokseumawe.

\section{PENUTUP}

\section{Kesimpulan}

Adapun hasil uraian kesimpulan masingmasing variable penelitian yang penulis rangkum yaitu sebagai berikut :

1. Bahwa analisis persyaratan Benfords Law dalam data nilai transaksi Pabean di Direktorat Jenderal Bea dan Cukai Cabang Kota Lhokseumawe itu sudah memenuhi persyaratan yang di syaratkan oleh hukum benfords dan sudah sesuai dengan ketentuan hukum benfords, sehingga bisa di analisis lebih lanjut dengan menggunakan Benfords Law untuk mendeteksi prediksi temuan audit.

2. Penggunaan Benfords Law untuk melihat perbedaan antara nilai data transaksi pabean yang ada di Direktorat Jenderal Bea dan Cukai Cabang Kota Lhokseumawe dengan harapan Hukum Benfords, Juga menunjukkan bahwa terdapat perbedaan pola frekuensi actual dengan pola frekuensi Benfords Law.

3. Analisis Benfords Law untuk melihat perbedaan Proporsi antara nilai data transaksi pabean yang ada di Direktorat Jenderal Bea dan Cukai Cabang Kota Lhokseumawe dengan menggunakan Benfords Law untuk memprediksi temuan audit berdasar kan penelitian terdahulu bahwa sanya hasil analisis perbedaan proporsi antara nilai aktual data transaksi pabean Direktorat Jenderal Bea dan Cukai Cabang Kota Lhokseumawe dengan nilai hasil frekuensi Benfords Law ini sudah efektif menunjukkan bahwa Benfords Law ini bisa untuk mendeteksi temuan audit

\section{Saran}

Adapun Terdapat beberapa saran dalam penelitian ini yang nantinya dapat berguna dan dapat memberikan arah bagi penelitian selanjutnya, yaitu sebagai berikut :

1. Berdasarkan dari hasil penelitian, maka penulis mengharapkan bahwa pihak Direktorat Jenderal Bea dan Cukai Cabang Kota Lhokseumawe itu benar-benar menyajikan data yang akurat dan sesuai dengan apa yang terjadi di lapangan. Dan juga pihak Direktorat Jenderal Bea dan Cukai perlu mengoptimalkan tingkat pengawasan kerja internal yang ketat supaya jauh terhindar dari unsur-unsur kecurangan.

2. Peneliti selanjutnya dapat lebih maksimal memperoleh data transaksi perusahaan atau instansi pemerintahan, bila perlu menambah jumlah data penelitiannya misalnya diambil data transaksi penjualan atau data transaksi pembelian, karena lebih banyak data yang di analisis dengan hukum benford ini lebih bagus,sehingga penelitian selanjutnya akan lebih baik.

3. Peneliti selanjutnya disarankan menambah variable penelitian lainnya seperti nilai firs digit 
(FD),second digit (SD), three digit (TD),firs second digit (F2D),First-ThreeDigit (F3D),Last-TwoDigit (L2D), dan lain-lain yang dapat memprediksi temuan audit dengan penggunaan Benfords Law.

\section{DAFTAR PUSTAKA}

Agoes,sukrisnoe, 2012,auditing : pemeriksaan akuntansi buku 1 edisi 4 penerbit salemba empat.

Arkan, Muhamad Mufti. 2010. Analisis Penggunaan Benford's Law Dalam Perencanaan Audit pada Direktorat Jenderal Bea dan Cukai. Simposium Nasional Akuntansi XIII. Purwokerto.

Cho, Wendy K.T and Gaines, Brain J., Breaking the (Benford) Law: Statistical Fraud Detection in Campaign Finance, The American Statistician, August, 2007

Durtschi, C., Hillison, W. and Pacini, C,. 2004. The Effective Use of Benford's Law to Assist in Detecting Fraud in Accounting Data. Journal of ForensicAccounting Vol. V (2004), pp. 17-34.

EmilyaUllyArtha,2015,Analisa CAATS (Computer Asisted Audit Techniques) untuk identifikasi data log firewall, SEMNAS TEKNOMEDIA, ISSN :2302-3805.

FitriAnnisa :Lutfi Haris,2011,Deteksi Indikasi Fraud Dengan Teknologi Audit, Seminar Nasional Aplikasi Teknologi Informasi (SNATI),ISSN:1907-5022

http://itadf.blogspot.co.id/2012/09/benfordlaw.html.diakses pada tanggal 31/07/2017.

https://www.academia.edu/20057301/Pengertian_ Perencanaan_Audit., diaksespadatanggal 31/07/2017.

Indri, Riesfandiari, Pengaruh Audit di Bidang Kepabeanan Terhadap Kepatuhan Importir Umum di Lingkungan Kantor Wilayah IV Jakarta, UI, 2006

IsworoNugroho,2009,Peranan Teknologi Informasi Dalam Audit Sistem Informasi Komputerisasi Akuntansi, Dinamika Informatika Vol1No 2, ISSN : 2085-3343

MahendraAdiNugroho“AuditLingkunganTI:Perspe ktifdan dampak pada proses auditing secara komprehensif", Jurnal Pendidikan Akuntansi Indonesia,2011
Nigrini, Mark J., A Taxpayer Compliance Aplication of Benford's Law, The Journal of the American Taxation Association, 18,1 : 1996

Nigrini, Mark J.. Benford's Law: Applications for Forensic Accounting, Auditing, and Fraud Detections. New Jersey: John Wiley \& Sons, Inc.. 2012.

Nigrini, Mark J. Digital Analysis Using Benford's Law : Test and Statistic for Auditors, Global Audit Publication, Vancouver,2000.

Purwoko, Agung Bayu, Pemilihan Obyek Audit Kepabeanan Berdasarkan Profil Importir pada DJBC, Jurnal Akuntansi Keuangan Negara, BPPK, 2004

PutuMega SelvyaAviana,2012,Penerapan Pengendalian Internal Dalam Sistem Informasi Akuntansi Berbasis Komputer, Jurnal Ilmiah Mahasiswa Akuntansi Vol 1 No 4

RadianVictorImbar,"Pelaksanaan kontrol dan audit sistem informasi pada organisasi",Jurna linformatikaUKM,Vol1No1 Tahun 2005

Rahayu, Tunjung Sri and Adhariani, Desi, Assessing the Customs Value By the Use of Benford's Law: A Case Study, Journal of Economics Business and Accounting,April, 2007

Undang-undang No. 17 tahun 2006 tentang perubahan atas undang-undang nomor 10 tahun 1995 tentang kepabeanan

Wibisono, Hermaz, Analisis Efektifitas Penggunaan Benford's Law Dalam Menilai Kewajaran Nilai Pabean sebagai Bagian Dari Perencanaan Audit di Kantor Pelayanan Utama Bea dan Cukai Tipe A Tanjung Priok, Sekolah Tinggi Ilmu Ekonomi Swadaya, 2009

http://www.konsistensi.com/2013/04/teori-sampeldan-sampling-penelitian.html?m=1.,diakses pada tanggal 31/01/2019. 
